https://doi.org/10.1007/s10694-019-00834-8

\title{
A Review of Design Values Adopted for Heat Release Rate Per Unit Area
}

\author{
Charlie Hopkin* (1), OFR Consultants, Jactin House, 24 Hood Street, \\ Manchester M4 6WX, UK, School of Mechanical, Aerospace and Civil \\ Engineering, The University of Manchester, Manchester M13 9PL, UK \\ Michael Spearpoint, OFR Consultants, Jactin House, 24 Hood Street, \\ Manchester M4 6WX, UK \\ Danny Hopkin, OFR Consultants, Jactin House, 24 Hood Street, Manchester \\ M4 6WX, UK; Department of Civil and Structural Engineering, The \\ University of Sheffield, Sheffield S1 3JD, UK
}

Received: 21 October 2018/Accepted: 19 February 2019

\begin{abstract}
When conducting fire and smoke modelling it is important to adopt an appropriate design fire. Calculations may adopt a design fire that is represented in terms of a heat release rate per unit area (HRRPUA). This paper provides a historical review of recommended values that are predominantly used in the UK as well as values from other jurisdictions where appropriate. It has been determined that many of the HRRPUA values provided in UK guidance are derived from ten fire incidents for industrial fires in the 1960s and 1970s, and five wood crib experiments undertaken in the 1960s. The HRRPUA values originally calculated from these incidents and experiments ranged from $86 \mathrm{~kW} / \mathrm{m}^{2}$ to $650 \mathrm{~kW} / \mathrm{m}^{2}$. The data was gradually adapted in various forms to consider shops and retail buildings, offices, hotel rooms and residential buildings, where variations in recommended values have occurred over time due to adjustments and calculations from various authors. In light of the observations, this paper provides updated recommended values from literature which relate to specific occupancies and building types. These are summarised as a range of potential values, such as $270 \mathrm{~kW} / \mathrm{m}^{2}$ to $1200 \mathrm{~kW} / \mathrm{m}^{2}$ for shops and $150 \mathrm{~kW} / \mathrm{m}^{2}$ to $650 \mathrm{~kW} /$ $\mathrm{m}^{2}$ for offices, where designers will need to take care in considering the relevant source material.
\end{abstract}

Keywords: Heat release rate per unit area, Design fire, Fire and smoke modelling

* Correspondence should be addressed to: Charlie Hopkin, E-mail: charlie.hopkin@postgrad. manchester.ac.uk 


\section{Introduction}

Heat release rate per unit area (HRRPUA) is commonly used as a design input for fire and smoke modelling. The heat release rate (HRR) of a fire may be calculated from the area of a fire using the following equation [1]:

$$
\dot{Q}=\dot{Q}^{\prime \prime} \mathrm{A}_{\text {fire }}
$$

where $\dot{Q}$ is the total HRR $(\mathrm{kW}), \dot{Q}^{\prime \prime}$ is the HRRPUA $\left(\mathrm{kW} / \mathrm{m}^{2}\right)$ and $\mathrm{A}_{\text {fire }}$ is the area of fire involvement $\left(\mathrm{m}^{2}\right)$. This approach to determining HRR is typically adopted in circumstances where the fire is fuel bed controlled (i.e. controlled by the availability of fuel) and combustibles can burn freely without being limited due to a lack of ventilation. Using this approach assumes a HRRPUA value for a specific fuel type or fuel package (e.g. an item of furniture) and example values can be found in the literature, including standard text books such as Drysdale [2] and the SFPE Handbook of Fire Protection Engineering [3].

Alternatively, rather than using a specific fuel type or package, the HRR can be calculated as a function of the occupancy type for which a representative HRRPUA is applied and this value is then assumed for a specified area. The area may be taken to be a proportion of the enclosure floor area, to represent a designated fire footprint, or could be taken as the area of the entire enclosure. The fire footprint may represent the surface area of one or more fuel packages or could be related to an expected area of fire involvement, for example for a fire which has been limited by the actuation of a sprinkler system with an assumed sprinkler head spacing arrangement. With respect to this interpretation of area of fire involvement the Eurocode for actions on structures exposed to fire, EN 1991-1-2 [4], refers to $\mathrm{A}_{\text {fire }}$ as "the maximum area of the fire which is the fire compartment in case of uniformly distributed fire load but which may be smaller in case of a localised fire" [4]. Whilst EN 1991-1-2 is a code dedicated to structural response in fire, the content cited in Annex E relates to a generic description of enclosure fire development, giving guidance on fuel and ventilation-controlled regimes in terms of HRR and the relationship with time.

PD 7974-1:2003 [1] is a UK published document which provides guidance on the initiation and development of fire within the enclosure of origin and provides guideline values for various occupancies, reproduced in Table 1. The recommended HRRPUA values given in PD 7974-1:2003 reference NFPA 92B and the latest revision of UK guidance document CIBSE Guide E [5] also provides values consistent with those given in NFPA 92B. Thus, in its caveat of suggested HRRPUA values, PD 7974-1:2003 notes that "this information should be treated with care, as it is predominantly of US origin and therefore may not always be representative of UK occupancies".

The review herein results from discussions in the process of the revision of PD 7974-1 likely to be published in 2019, where uncertainty arose as to the origins and appropriate application of HRRPUA values given in the previous 2003 edition. This review is separated out into six main categories based on the building/ 


\section{Table 1}

PD 7974-1:2003 [ 1 ] suggested HRRPUA for fuel bed controlled fires

\begin{tabular}{ll}
\hline Occupancy & HRRPUA $\left(\mathrm{kW} / \mathrm{m}^{2}\right)$ \\
\hline Shops & 550 \\
Offices & 290 \\
Hotel rooms & 250 \\
Industrial excluding storage & $90-620$ \\
& Depending upon fuel and arrangement \\
\hline
\end{tabular}

occupancy type: industrial; shops and retail (mercantile); offices; hotel rooms; residential; and other types. These categories broadly align with those described in PD 7974-1:2003, given in Table 1.

Following a review of the history of HRRPUA values of the six occupancy categories, conclusions and recommendations are made on what may represent reasonable design values that can be incorporated into the revised edition of PD 7974-1, as well as discussion on what further work needs to be considered.

\section{Determination of HRRPUA}

In the determination of HRRPUA from experimental data, the area of fire involvement $\left(\mathrm{A}_{\text {fire }}\right)$ could be derived in multiple ways, such as by using the area of the fuel or the area of a burning enclosure, or by using less precise measures such as the direct visual observations or by inspecting images (video/still photographs) recorded during experiments. Experiments may include single or multiple burning items, and the HRR $(\dot{Q})$ is typically determined either by oxygen calorimetry or an assessment of the mass of fuel consumed with respect to time, in the latter case by adopting a representative value for the heat of combustion of the fuel. The heat of combustion may be expressed either as a total or effective value, although in some work it is not always clear which of these has been adopted. Either approach produces a HRR curve where the HRR will typically fluctuate or change over time. The raw mass loss or heat release measurements from experiments may undergo some smoothing to reduce noise in the data, for example by applying the Savitzky-Golay smoothing filter, as illustrated by Staggs [6] for cone calorimeter mass data. Specific to HRR, Evans and Breden [7] note that such data can be made "more attractive by smoothing techniques".

Values for HRRPUA are easily determined for fuels which burn in a relatively steady-state manner from:

$$
\dot{Q}^{\prime \prime}=\frac{\dot{Q}}{\mathrm{~A}_{\text {fire }}}
$$

However, in reality most fuels do not burn with a steady-state HRRPUA, even if the nominal area of burning remains constant. In such a case the HRRPUA can be determined by: 


$$
\dot{Q}^{\prime \prime}=\frac{\overline{\dot{Q}}}{\mathrm{~A}_{\text {fire }}}
$$

where $\bar{Q}$ is the average HRR over a defined period of burning (where $\dot{Q}^{\prime \prime}$ is referred to herein as the 'individual average HRRPUA'). The assumption of a fixed burning area is applied in NFPA 271 [8], for example. Fuels such as liquid hydrocarbons in pool configurations are often treated as though they burn at a steadystate, but in practice the turbulent flames results in a HRR that fluctuates around a mean value. Even this assumption may not account for the heat transfer effects to and from the fuel container or the initial (albeit rapid) growth period. Furthermore, most containers do not have perfectly flat bases. These combined factors result in the HRR not immediately reaching a maximum from zero or vice versa in the form of a step-function.

Fuel packages that may consist of several materials are unlikely to burn with a steady-state HRR but will typically involve growth and decay phases with an associated change in the area of burning. The piece-wise HRRPUA can be calculated at defined time-steps and the overall HRRPUA given by:

$$
\dot{Q}^{\prime \prime}=\frac{\sum_{t=t_{n}}^{t=t_{1}}\left(\frac{\dot{Q}}{\mathrm{~A}_{\text {fire }}}\right)_{t}}{n}
$$

where $\left(\frac{\dot{Q}}{\mathrm{~A}_{\text {fire }}}\right)_{t}$ is the HRRPUA at a given time-step $t$ for the instantaneous HRR $(\dot{Q})$ and instantaneous area $\left(\mathrm{A}_{\text {fire }}\right)$, and $n$ is the number of time-steps. The calculation can be carried out over the total duration $\left(t_{\text {total }}\right)$ of burning or some specified restricted timescale as appropriate. The determination of the total duration of burning is also subject to interpretation as in practice a fire experiment may be terminated before complete combustion has ceased. Within standard procedures, tests may be terminated under stated conditions, for example NFPA 271 [8], where specified durations have elapsed, or when the mass loss rate has dropped below a defined criterion.

Those fuel packages that exhibit growth and decay phases will result in a peak HRR. Experimentally the determination of a peak value will be affected by the sampling frequency of the instruments and whether any smoothing of data is carried out. Often the peak HRR is synonymous with the maximum HRR. However, Mowrer and Williamson [9] note that composite products and materials exhibit complex burning behaviour which may result in more than one peak in the HRR. The peak HRRPUA can be determined by:

$$
\dot{Q}_{\text {peak }}^{\prime \prime}=\left(\frac{\dot{Q}}{\mathrm{~A}_{\text {fire }}}\right)_{\text {peak }}
$$

This paper defines the maximum $\left(\dot{Q}_{\max }^{\prime \prime}\right)$ as the greatest HRRPUA for a given curve in circumstances where there may be more than one peak. Where a curve 


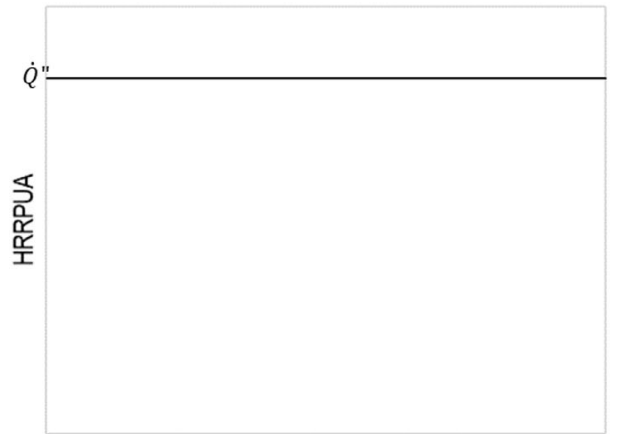

Time, $\mathrm{t}$

(a) Idealised steady-state

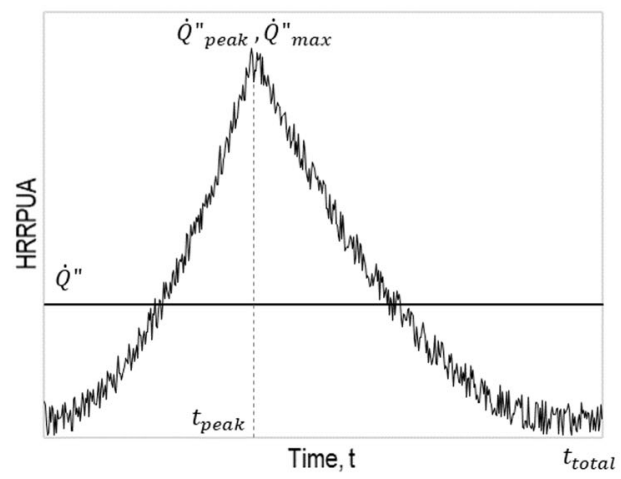

(c) 'Simple' burning item

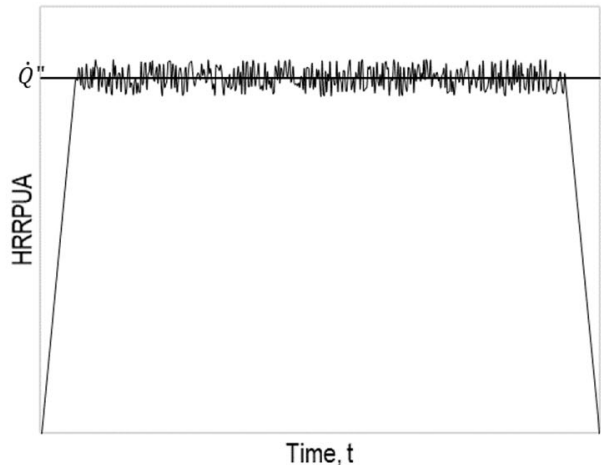

(b) Representative steady-state (e.g. liquid hydrocarbon pool fire, assuming no heat transfer effects to the fuel container)

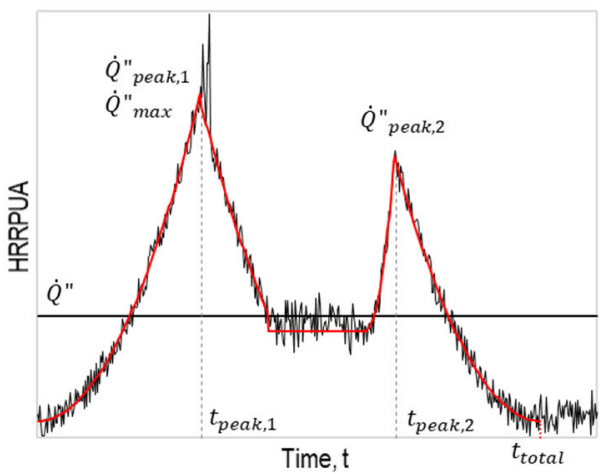

(d) 'Complex' burning item (with indicative 'smoothing' shown in red)

\section{Figure 1. Exemplar individual HRRPUA curves.}

only has one peak, then the maximum and the peak are considered equivalent within the context of the discussion in this paper.

With respect to the above methods of determining HRRPUA, exemplar individual HRRPUA curves are shown in Fig. 1.

When data is available for two or more separate experiments (under the same experimental conditions) then a combined average HRRPUA $\left(\overline{\dot{Q}^{\prime \prime}}\right)$ can be calculated from the individual average HRRPUA values $\left(\dot{Q}^{\prime \prime}\right)$. Similarly, a combined average maximum HRRPUA $\left({\overline{\dot{Q}^{\prime \prime}}}_{\max }\right)$ can be determined from individual maximum HRRPUA $\left(\dot{Q}_{\max }^{\prime \prime}\right)$ values. Clearly care is required when interpreting reported HRRPUA values in terms of the calculation method and whether values are an individual or combined, average or maximum HRRPUA. Specific to this paper, PD 7974-1:2003 does not mention whether the HRRPUA values are intended to represent average or maximum values. 
Finally, as discussed by Krasny et al. [10], when measuring the HRR of a burning item the presence of an enclosure can cause air vitiation effects, generate unsymmetrical air flow patterns and enhance the burning rate due to radiation feedback from the hot surfaces and upper gas layer. To overcome these enclosure effects, standard test methods for measuring HRR are operated in an open configuration, allowing an unrestricted flow of air to the combustion zone. Thus, it is possible that HRRPUA values cited in the literature do not include enclosure effects, although these effects may be relevant to a design application. The New Zealand verification method C/VM2 [11] includes an enhancement to the HRR at flashover to account for radiation from the upper gas layer in its design procedure.

\section{Occupancy Types}

\subsection{Industrial}

In 1977, Theobald [12] considered the growth and development of fire in industrial buildings. This work summarised a series of ten fire incidents and five experimental fires, reproduced in Table 2. These fire incidents and experimental fires were taken from previous research undertaken by Theobald [13] and Heselden et al. [14], respectively. The fire incidents included surveys of five storage buildings, one factory, two workshops and a hospital research unit, with enclosure areas ranging from $170 \mathrm{~m}^{2}$ to over $10,000 \mathrm{~m}^{2}$. Building contents of the fire incidents varied from packaged goods, cardboard, timber with three of the fire incidents including mixed combustibles (Table 2). Silcock [15] outlined the surveying method and fire reports, where several details were recorded by fire and rescue service personnel following the incident, including the location, spread and the extent of the fire.

To calculate HRRPUA related to each incident, Theobald [12] considered the estimated mass of fuel consumed, and the estimated fire duration, relative to the recorded fire damage area. This provided an estimated burning rate in $\mathrm{kg} / \mathrm{m}^{2} / \mathrm{s}$. To calculate the equivalent burning rate in $\mathrm{kW} / \mathrm{m}^{2}$, Theobald adopted a fixed heat of combustion value of $13 \mathrm{MJ} / \mathrm{kg}$, equivalent to that of wood.

PD 7974-1:2003 [1] references Theobald's work, recommending a HRRPUA of $90 \mathrm{~kW} / \mathrm{m}^{2}$ to $620 \mathrm{~kW} / \mathrm{m}^{2}$ for fires occurring in industrial occupancies. These values approximately equate to the minimum and maximum values for the fire incidents summarised by Theobald, and shown in Table 2. Thus, for industrial fires, the work of Theobald is based on fire incidents and experiments undertaken in the UK and the PD 7941-1:2003 caveat relating to the US origin of the information is inaccurate.

The first edition of NFPA 92B [16], published in 1991, recommends a HRRPUA of $260 \mathrm{~kW} / \mathrm{m}^{2}$ for industrial fires, referring to Theobald's work. While NFPA 92B does not explicitly state why the $260 \mathrm{~kW} / \mathrm{m}^{2}$ value is recommended for industrial fires, it aligns with Incident 2 for the building containing vehicles, petrol and paint given in Table 2. This value has been adopted in subsequent revisions of NFPA 92B. 


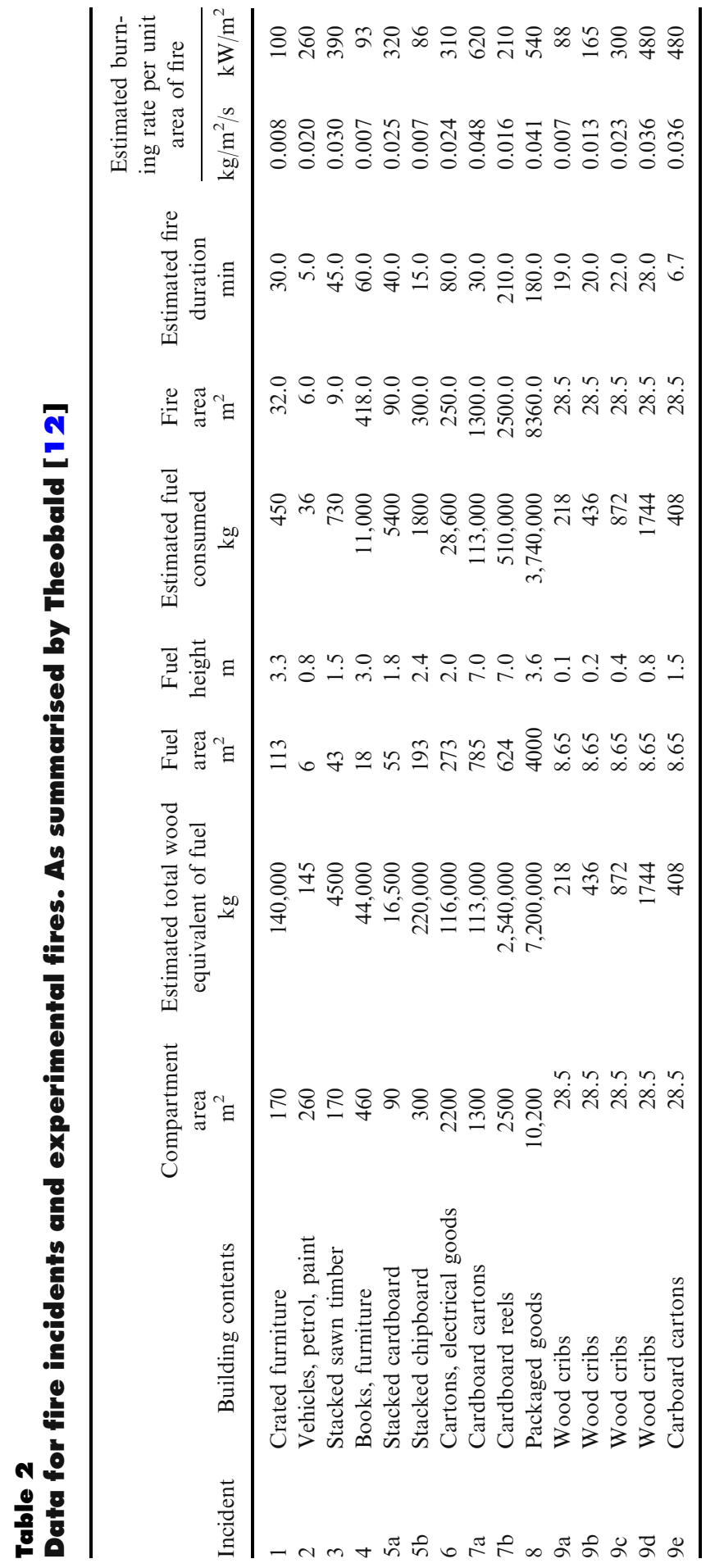




\subsection{Shops and Retail (Mercantile)}

In 1979, Morgan [17] provided a design summary of smoke control methods in enclosed shopping complexes. In this document, Morgan discusses recommended design fire HRR for fires originating in shops and mentions that statistical information on shops is limited. However, Morgan specifies that for shops fitted with sprinkler systems, fewer than $5 \%$ resulting in sprinkler actuation become greater than $5 \mathrm{MW}$, subsequently stating that a $5 \mathrm{MW}$ design fire "has become widely accepted as a maximum fire [size] for design purposes in view of its low probability of occurring". Morgan equates this to a fire of base dimensions of $3 \mathrm{~m}$ by $3 \mathrm{~m}$ and a HRRPUA of $500 \mathrm{~kW} / \mathrm{m}^{2}$. Although the aforementioned $9 \mathrm{~m}^{2}$ base would result in a HRRPUA of $555 \mathrm{~kW} / \mathrm{m}^{2}$ for a $5 \mathrm{MW}$ fire, the specified dimensions are considered to broadly align with a $10 \mathrm{~m}^{2}$ fire area with a $12 \mathrm{~m}$ perimeter $[18,19]$. Morgan specifies that the selected HRRPUA is the 'average' of values obtained in experimental sprinklered fires, but does not comment on whether this represents a combined average $\left(\overline{\dot{Q}^{\prime \prime}}\right)$ or a combined average maximum $\left({\overline{\dot{Q}^{\prime \prime}}}_{\max }\right)$ across the experiments. Whilst Morgan does not specify how the fire area was determined, previous work by Hinkley [20] in 1971 on the control of smoke in enclosed shopping centres notes "in the absence of other information, it is suggested that a fire $3 \mathrm{~m} \times 3 \mathrm{~m}$ should be taken". While not explicitly stated, this appears to align with a typical spacing between sprinkler heads, with Hinkley [21] stating for a $3 \mathrm{~m}$ by $3 \mathrm{~m}$ fire- "this is considered reasonable if the fire is being controlled by sprinklers". Hinkley [21] also refers to circumstances where a fire is limited by sprinklers "so that its heat output is about $5 \mathrm{MW}$ " and later that "experiments... have shown that when sprinklers were operating its peak burning rate was about $1 / 2 \mathrm{MW} / \mathrm{m}^{2}$ ". The experiments involved the burning of $1.2 \mathrm{~m}$ wide by $2.4 \mathrm{~m}$ long by $1.8 \mathrm{~m}$ high storage rack that were loaded with approximately $100 \mathrm{~kg}$ of combustible materials, including polystyrene tiles, polyurethane foam, wood, wool and cardboard on wooden slats.

In reviewing the origins of the $5 \mathrm{MW}$ retail design fire, Law [22] discusses the work of Hinkley. Law notes that in Hinkley's experiments, an unsprinklered fire results in a maximum HRRPUA of approximately $1000 \mathrm{~kW} / \mathrm{m}^{2}$, a sprinklered shielded fire $300 \mathrm{~kW} / \mathrm{m}^{2}$ and a sprinklered unshielded fire $100 \mathrm{~kW} / \mathrm{m}^{2}$. The $5 \mathrm{MW}$ fire is described as representative of a shielded sprinklered fire located in the 'worst' possible location, i.e. at the centre of a grid of four sprinkler heads spaced $3 \mathrm{~m}$ apart. This is described as a 'typical' sprinkler spacing, although Law notes that the maximum spacing could be up to $3.6 \mathrm{~m}$ by $3 \mathrm{~m}\left(10.8 \mathrm{~m}^{2}\right)$. Law suggests that the sprinklers are assumed to stop fire spread beyond the $3 \mathrm{~m}$ by $3 \mathrm{~m}$ area and remove half of the energy content by cooling the gases.

By referencing Morgan [17], NFPA 92B [16] in 1991 discussed an approximate HRRPUA of $50 \mathrm{Btu} / \mathrm{s} / \mathrm{ft}^{2}\left(568 \mathrm{~kW} / \mathrm{m}^{2}\right)$ for mercantile occupancies, for a design fire size of approximately $5000 \mathrm{Btu} / \mathrm{s}(5275 \mathrm{~kW})$. The 2012 edition of NFPA 92 [23] noted that this design fire size is based on a "statistical distribution of fire sizes in shops in the United Kingdom that include sprinkler protection", where less than $5 \%$ of fires exceeded $5275 \mathrm{~kW}$ and geometrically this fire has been described as having an area of $3.1 \mathrm{~m}$ by $3.1 \mathrm{~m}\left(9.6 \mathrm{~m}^{2}\right)$. NFPA 92B's $568 \mathrm{~kW} / \mathrm{m}^{2}$ 
was subsequently referenced and simplified in PD 7974-1:2003 [1] to $550 \mathrm{~kW} / \mathrm{m}^{2}$, more closely aligning with Morgan's comments regarding a $5 \mathrm{MW}$ design fire and $9 \mathrm{~m}^{2}$ fire area. The precursor to PD 7974-1, Draft for Development DD 2401:1997 [24], recommended $500 \mathrm{~kW} / \mathrm{m}^{2}$ for retail building use and similarly, Technical Memoranda TM19:1995 [25] recommended $500 \mathrm{~kW} / \mathrm{m}^{2}$ for shops.

Expanding on Morgan's guidance published in 1979, Morgan and Gardner [26] authored BR 186 'Design principles for smoke ventilation in enclosed shopping centres'. This design guidance did not provide a recommended value for HRRPUA but refers to the $3 \mathrm{~m}$ by $3 \mathrm{~m}$ sprinkler-controlled fire which, as stated in BR 186, became "the accepted basis in the UK for a smoke ventilation system in a sprinklered shopping centre". Likewise, BR 258 [18] 'Design approaches for smoke control in atrium buildings', published in 1994, refers to a $10 \mathrm{~m}^{2}$ sprinklered retail fire but does not state the equivalent HRR or HRRPUA.

In the above works on the $5 \mathrm{MW}$ design fire, it is not always explicitly stated whether the HRR and HRRPUA values given are referring to the total HRR or the convective portion only. However, it may be inferred from several sources that it is representative of the convective HRR only, where Morgan [17] refers to the "heat carried by the hot gases" when discussing fire size for the design of smoke control systems, Hansell and Morgan [18] states a "convective heat flux" for design fires associated with atria and Morgan and Gardner [26] adopt the "heat flow rate" when calculating the smoke temperature for a $5 \mathrm{MW}$ fire. Therefore, the adoption of these values for the total HRR or HRRPUA would not directly align with the intent of the original works. Subsequent to this, BR 368 [19], Morgan et al.'s 'Design methodologies for smoke and heat exhaust', which builds upon both BR 186 and BR 258, recommends a HRRPUA of $625 \mathrm{~kW} / \mathrm{m}^{2}$ for steady-state retail design fires where sprinkler protection is provided, and $1200 \mathrm{~kW} / \mathrm{m}^{2}$ where there are no sprinklers. For the former, the commonly adopted $5 \mathrm{MW}$ fire is considered explicitly representative of convective HRR at $75 \%$ of the total HRR, resulting in a total maximum HRR of $6250 \mathrm{~kW}$ for a fire area of $10 \mathrm{~m}^{2}$. The latter $1200 \mathrm{~kW} / \mathrm{m}^{2}$ unsprinklered value broadly aligns with a $1000 \mathrm{~kW} / \mathrm{m}^{2}$ convective HRRPUA described by Law [22] for Hinkley's original experiments.

\subsection{Offices}

Law [27] discussed fire and smoke hazards in air-supported structures as part of a paper first published in 1980. Within this, Law further summarised fire incidents in industrial premises previously discussed by Theobald [12]. Law proposed that values of $0.02 \mathrm{~kg} / \mathrm{m}^{2} / \mathrm{s}$ and $290 \mathrm{~kW} / \mathrm{m}^{2}$ for the mass burning rate per unit area and HRRPUA, respectively, may be adopted when considering furniture fires in offices and residential accommodation. While not explicitly stating how these values were derived, they approximately equate to the combined average mass burning rate per unit area and HRRPUA values from Theobald's industrial fire incidents (i.e. Incidents 1 to 8 in Table 2). The $290 \mathrm{~kW} / \mathrm{m}^{2}$ HRRPUA recommendation was subsequently referenced and adopted in NFPA 92B [16] when considering HRRPUA for use in smoke management design of offices. PD 7974-1:2003 
references NFPA 92B for its $290 \mathrm{~kW} / \mathrm{m}^{2}$ recommended design value for offices with the inaccurate caveat relating to the information being of US origin.

Separate to Law's paper, Morgan and Hansell [28] considered the implications of fire sizes and sprinkler effectiveness in offices. When proposing a method for determining a HRR for office design fires, a HRRPUA of $260 \mathrm{~kW} / \mathrm{m}^{2}$ was used. This value was again derived from Theobald [12] and applying a fixed fire load per unit area of $57 \mathrm{~kg} / \mathrm{m}^{2}$. Morgan and Hansell stated that this fixed fuel load was adopted from unpublished surveys carried out by Melinek from 1965 to 1967, where it was determined that office fuel load was less than $57 \mathrm{~kg} / \mathrm{m}^{2}$ in approximately $95 \%$ of cases. This fuel load per unit area corresponded to mass burning rate per unit area of $0.0144 \mathrm{~kg} / \mathrm{m}^{2} / \mathrm{s}$ for the 'wood crib' curve shown in Fig. 2 (reproduced from Theobald [12]). However, instead of using the wood-equivalent $13 \mathrm{MJ} / \mathrm{kg}$ heat of combustion adopted by Theobald, Morgan and Hansell applied an alternative value of $18 \mathrm{MJ} / \mathrm{kg}$. Morgan and Hansell [28] also note that the resulting HRRPUA is "close to the heat release rate per unit area of $290 \mathrm{~kW} / \mathrm{m}^{2}$ for offices quoted by Law".

In their following work on calculating smoke flows in atria, Morgan and Hansell [29] discussed problems arising from their previous interpretation of Theobald [12], where they assumed that a 'wood crib' curve (Fig. 2) would be representative of fuel loads found in offices, expressing these values as 'equivalent wood loads'. In their previous calculation, Morgan and Hansell applied Theobald's data for the mass burning rate of fuel per unit area (or the burning rate per unit area of fire). However, as noted by Law in her comments on the paper [30], the fuel area of the wood crib experiments was one-third of the enclosure area and therefore was not representative of the burning rate per unit area of the entire enclosure. In response, Morgan and Hansell discussed uncertainties in the fire incidents as to how the fuel was distributed within the space [31]. Theobald's industrial fires data was therefore replotted to consider the burning rate per unit area of available fuel

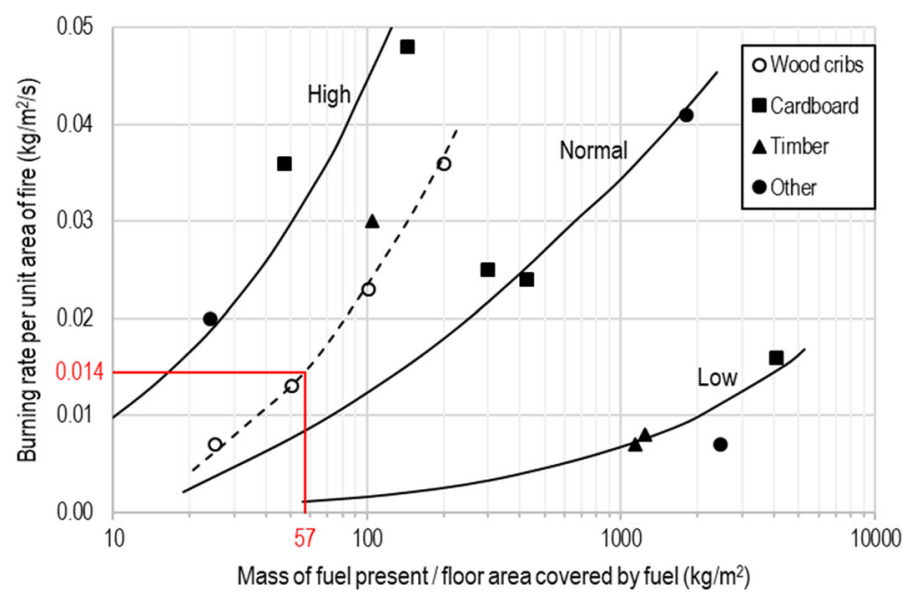

Figure 2. Fuel load density against burning rate per unit area of fire. From Theobald [ 12 2]. 


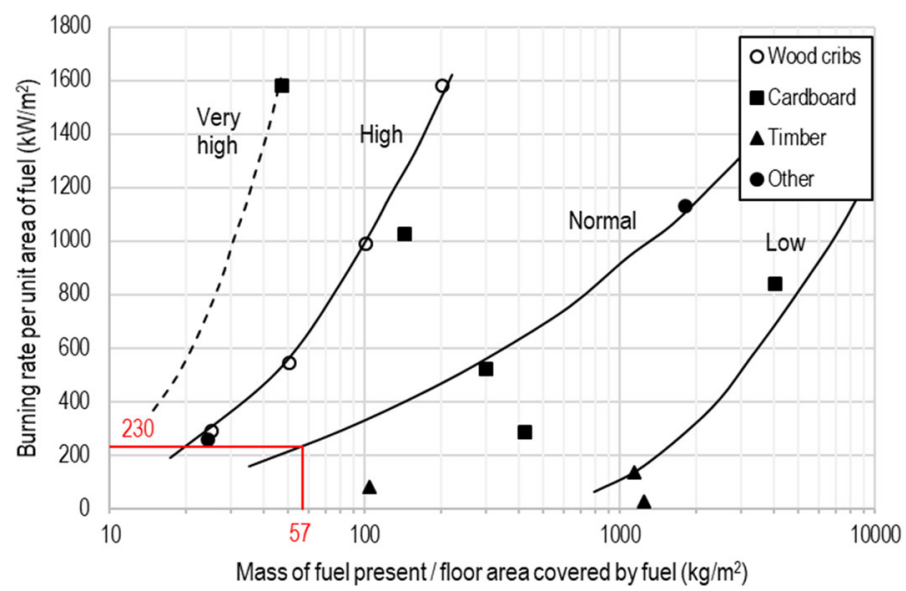

\section{Figure 3. Fuel load density against burning rate per unit area of available fuel. From Morgan and Hansell [29].}

within the enclosure instead of the burning rate per unit area of fire damage (per Table 2), to produce the new relationships shown in Fig. 3. Adopting a heat of combustion of $13 \mathrm{MJ} / \mathrm{kg}$ for wood instead of the previously used $18 \mathrm{MJ} / \mathrm{kg}$, again for a design fire load of $57 \mathrm{~kg} / \mathrm{m}^{2}$, Morgan and Hansell proposed a revised HRRPUA of $230 \mathrm{~kW} / \mathrm{m}^{2}$ for offices, with an equivalent mass burning rate of $0.0177 \mathrm{~kg} / \mathrm{m}^{2} / \mathrm{s}$. In comparison, if Morgan and Hansell's original $18 \mathrm{MJ} / \mathrm{kg}$ heat of combustion value was instead adopted, this would produce a HRRPUA of approximately $320 \mathrm{~kW} / \mathrm{m}^{2}$.

BR 368 [19] recommends a HRRPUA of $255 \mathrm{~kW} / \mathrm{m}^{2}$ for open-plan offices and also refers to a value of $270 \mathrm{~kW} / \mathrm{m}^{2}$ for cellular offices. The $255 \mathrm{~kW} / \mathrm{m}^{2}$ value aligns closely with the $230 \mathrm{~kW} / \mathrm{m}^{2}$ to $260 \mathrm{~kW} / \mathrm{m}^{2}$ values calculated by Morgan and Hansell. The latter $270 \mathrm{~kW} / \mathrm{m}^{2}$ value relates to experiments undertaken by Ghosh [32] and others, where the total HRR of the fire was measured in a calorimeter with a $6 \mathrm{~m}$ by $6 \mathrm{~m}$ hood. The area of the fire was estimated from visual observations and photographs. Ghosh noted that, following sprinkler actuation, the HRRPUA reduced to $190 \mathrm{~kW} / \mathrm{m}^{2}$ and also stated that in the experiments, the maximum HRRPUA varied from $150 \mathrm{~kW} / \mathrm{m}^{2}$ to $650 \mathrm{~kW} / \mathrm{m}^{2}$.

BS 7346-4:2003 [33], a British Standard and code of practice on the 'Functional recommendations and calculation methods for smoke and heat exhaust ventilation systems, employing steady-state design fires' almost universally adopts the same HRRPUA values as those given in BR 368 for all building types and circumstances. However, there is a single exception where BS 7346-4 recommends a HRRPUA of $225 \mathrm{~kW} / \mathrm{m}^{2}$ for an office fire with standard response sprinklers, contrary to BR 368 which recommends $255 \mathrm{~kW} / \mathrm{m}^{2}$ irrespective of whether sprinklers are included or not. It is suspected by the authors of this paper that the $225 \mathrm{~kW} /$ $\mathrm{m}^{2}$ value given in BS 7346-4:2003 may have been the result of a typing error (i.e. from $255 \mathrm{~kW} / \mathrm{m}^{2}$ to $225 \mathrm{~kW} / \mathrm{m}^{2}$ ). 


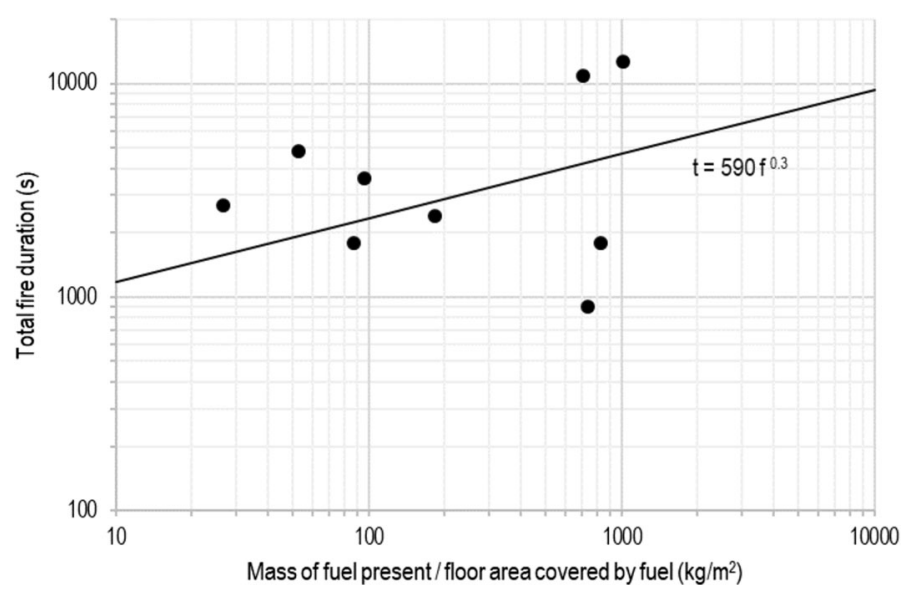

\section{Figure 4. Relationship between total fire duration and fuel load density. Adapted from Thomas and Theobald [42].}

Previously DD 240-1:1997 [24] and TM19:1995 [25] suggested a HRRPUA for offices of $250 \mathrm{~kW} / \mathrm{m}^{2}$ and this value is currently adopted in EN 1991-1-2 [4]. These all likely relate back to Morgan and Hansell's $260 \mathrm{~kW} / \mathrm{m}^{2}$ value.

Yuen and Chow [34] revisited Morgan and Hansell's work on offices to propose a new method of selecting design fires. To capture uncertainty associated with HRRPUA, a uniform distribution was proposed which ranged from $90 \mathrm{~kW} / \mathrm{m}^{2}$ to $360 \mathrm{~kW} / \mathrm{m}^{2}$. To obtain these upper and lower bounds, the work of Theobald [12] was again referenced. The same method of Morgan and Hansell was applied, with an assumed fire load per unit area of $57 \mathrm{~kg} / \mathrm{m}^{2}$, instead proposing limits from the 'normal' and 'high' ratios of fuel surface to fuel mass (shown in Fig. 2).

In separate work, Hietaniemi and Mikkola [35] collated information on a series of office workstation experiments by Madrzykowski [36], Madrzykowski and Watson [37], Kakegawa et al. [38], Ohlemiller et al. [39], where it was summarised that the maximum HRRPUA for these experiments ranged from $820 \mathrm{~kW} / \mathrm{m}^{2}$ to $1799 \mathrm{~kW} / \mathrm{m}^{2}$ with an average maximum $\left({\overline{\dot{Q}^{\prime \prime}}}_{\max }\right)$ of $1156 \mathrm{~kW} / \mathrm{m}^{2}$. In some instances, the HRRPUA represented a value averaged across the area of an entire burning enclosure (for example a $6.3 \mathrm{~m}$ by $6.3 \mathrm{~m}$ room for Kakegawa et al. [38].), and in others it related to the burning area of a single cubicle, or to the burning area of single items only. Given the different experimental conditions of the sources of data, the range of HRRPUA values for these fires is not necessarily representative of the same calculation methods and application (e.g. a single item versus an enclosure), resulting in potential inconsistencies across the dataset.

\subsection{Hotel Rooms}

Alongside their work on fires in offices, Hansell and Morgan [40] proposed fire characteristics for hotel bedrooms, with a recommended HRRPUA of $249 \mathrm{~kW} /$ $\mathrm{m}^{2}$. This was determined from a survey of fire loads in three bedrooms for a hotel 
near Heathrow Airport, referenced as a private communication, in combination with work by Pettersson et al. [41] on the magnitude of fuel loads in hotels. To determine the HRRPUA, Hansell and Morgan adopted a fuel load density of $357 \mathrm{MJ} / \mathrm{m}^{2}$ for the worst-case of the three surveyed hotel bedrooms, considered equivalent to $19.2 \mathrm{~kg} / \mathrm{m}^{2}$ for wood load fuel density assuming a heat of combustion of $18.6 \mathrm{MJ} / \mathrm{kg}$. This fuel load density aligned with the $85^{\text {th }}$ percentile of fuel loads observed by Pettersson et al. The time for the fuel to burn was derived from the work of Thomas and Theobald [42] on the burning rates and durations of fires, in an appendix to Theobald's work on industrial fires [12], where it was proposed that the following equation be adopted:

$$
t=590 f^{0.3}
$$

where $t(\mathrm{~s})$ is the total duration of burning and $f$ is the fuel load density $\left(\mathrm{kg} / \mathrm{m}^{2}\right)$. This relationship, reproduced in Fig. 4, was derived from the ten industrial fire incidents discussed by Theobald. Using this relationship, a fuel load density of $19.2 \mathrm{~kg} / \mathrm{m}^{2}$ results in a predicted burning duration of $1432 \mathrm{~s}(23.9 \mathrm{~min})$, producing a HRRPUA of $249 \mathrm{~kW} / \mathrm{m}^{2}$ for $357 \mathrm{MJ} / \mathrm{m}^{2}$. Although not discussed by Hansell and Morgan, applying the same method for the given hotel bedroom with the lowest fuel load density $\left(10.2 \mathrm{~kg} / \mathrm{m}^{2}, 190 \mathrm{MJ} / \mathrm{m}^{2}\right)$ results in a HRRPUA of $160 \mathrm{~kW} / \mathrm{m}^{2}$. In their subsequent revisiting of their work, discussed previously for HRRPUA values of offices, Morgan and Hansell proposed an adjusted HRRPUA for hotel bedrooms of $80 \mathrm{~kW} / \mathrm{m}^{2}$ to be applied across the entire floor area of the enclosure of fire origin [29].

In the above Thomas and Theobald method, fire duration is correlated with fire load density, not total fire load. As such, the correlation is independent of the enclosure size. The fire incidents considered by Theobald had enclosure areas which ranged from $90 \mathrm{~m}^{2}$ to $10,200 \mathrm{~m}^{2}$, with fuel areas ranging from $6 \mathrm{~m}^{2}$ to $4000 \mathrm{~m}^{2}$. For larger enclosures, the total fire duration will be heavily influenced by the time taken for the fire to spread to involve all fuel within the space. It is also improbable that all fuel burned near simultaneously, i.e. a fire that develops to flashover. Stern-Gottfried and Rein [43] note in their literature review of travelling fires that characteristic burning time (i.e. burning time per $\mathrm{m}^{2}$ of fuel) can be in the region of $19 \mathrm{~min}$ to $30 \mathrm{~min}$, a time period much less than many of the fire durations documented by Theobald and given in Fig. 4 (up to $210 \mathrm{~min}$ ). It may be that, in the context of the fires observed by Theobald, the total burning duration across the floor area was extended due to the occurrence of travelling fires. There are therefore limitations in adopting the relationship given by Thomas and Theobald outside of the context of the original industrial fire incidents.

Hansell and Morgan's value of $249 \mathrm{~kW} / \mathrm{m}^{2}$ is referenced in NFPA 92B [16] and the most recent 2018 edition of NFPA 92 [44] for a recommended HRRPUA for hotel rooms. This value was subsequently referenced and adopted in PD 79741:2003 [1], with a recommended HRRPUA of $250 \mathrm{~kW} / \mathrm{m}^{2}$, again making the inaccurate caveat relating to the information being of US origin.

BR 368 [19] recommends a HRRPUA of $250 \mathrm{~kW} / \mathrm{m}^{2}$ for hotel bedrooms where sprinkler protection is provided and the fire area is limited to $2 \mathrm{~m}^{2}$, or alterna- 
tively $100 \mathrm{~kW} / \mathrm{m}^{2}$ where there are no sprinklers and the fire area is assumed as the entire bedroom enclosure. Although the exact origin of the $100 \mathrm{~kW} / \mathrm{m}^{2}$ value is not specified, it appears to broadly align with both Morgan and Hansell's adjusted $80 \mathrm{~kW} / \mathrm{m}^{2}$ value and a design fire load of $81.6 \mathrm{MJ} / \mathrm{m}^{2}$ described by Pettersson et al. [41], recommended to be applied to the total room floor area. Applying the same method described by Morgan and Hansell [40] above for the Pettersson et al. $81.6 \mathrm{MJ} / \mathrm{m}^{2}$ fuel results in an equivalent wood fuel load fuel density of $4.4 \mathrm{~kg} / \mathrm{m}^{2}$. Assuming an $18.6 \mathrm{MJ} / \mathrm{kg}$ heat of combustion previously adopted by Hansell and Morgan in turn produces a HRRPUA of $88 \mathrm{~kW} / \mathrm{m}^{2}$.

\subsection{Residential}

For residential design, EN 1991-1-2 [4] recommends a HRRPUA of $250 \mathrm{~kW} / \mathrm{m}^{2}$, as did TM19:1995 [25]. In proposing a HRRPUA of $290 \mathrm{~kW} / \mathrm{m}^{2}$ for offices, Law [27] also noted that this value may be applied for residential occupancies. The adoption of such values is illustrated by Holborn et al. [45] who analysed fire sizes and fire growth rates using data from fire investigations, using a value of $250 \mathrm{~kW} /$ $\mathrm{m}^{2}$ for residential fires, referencing both NFPA 92B [16] and DD 240-1:1997 [24].

Fang and Breese [46] undertook sixteen burnout experiments to investigate fires in residential occupancies. These were performed in two rooms of $3.3 \mathrm{~m}$ wide, $3.3 \mathrm{~m}$ long and $2.4 \mathrm{~m}$ high, and $3.3 \mathrm{~m}$ wide, $4.9 \mathrm{~m}$ long and $2.4 \mathrm{~m}$ high, respectively. Included in the rooms were household furniture, linings and interior finishes described as "typical of actual occupancies". Using the maximum HRR in the enclosure combined with the total enclosure floor area, the maximum HRRPUA ranged from $320 \mathrm{~kW} / \mathrm{m}^{2}$ to $570 \mathrm{~kW} / \mathrm{m}^{2}$ for the experiments. This work is referenced in Klote and Milke's 'Principles of Smoke Management' [47], where they note that Fang and Breese determined a similar average maximum HRRPUA for residential occupancies as Morgan's $500 \mathrm{~kW} / \mathrm{m}^{2}$ value for retail

\section{Table 3}

\section{Fire load density and HRRPUA for different residential room types. From Hietaniemi and Mikkola [35]}

\begin{tabular}{lll}
\hline Room & \multicolumn{1}{c}{ Fire load density } & \multicolumn{1}{c}{ HRRPUA } \\
\hline Living room & $\alpha=405 \mathrm{MJ} / \mathrm{m}^{2}$ & $\alpha=565 \mathrm{~kW} / \mathrm{m}^{2}$ \\
& $\beta=96 \mathrm{MJ} / \mathrm{m}^{2}$ & $\beta=134 \mathrm{~kW} / \mathrm{m}^{2}$ \\
Bedroom & Average $=460 \mathrm{MJ} / \mathrm{m}^{2}$ & Average $=642 \mathrm{~kW} / \mathrm{m}^{2}$ \\
& $\alpha=522 \mathrm{MJ} / \mathrm{m}^{2}$ & $\alpha=805 \mathrm{~kW} / \mathrm{m}^{2}$ \\
& $\beta=233 \mathrm{MJ} / \mathrm{m}^{2}$ & $\beta=191 \mathrm{~kW} / \mathrm{m}^{2}$ \\
Kitchen & Average $=656 \mathrm{MJ} / \mathrm{m}^{2}$ & Average $=805 \mathrm{~kW} / \mathrm{m}^{2}$ \\
& $\alpha=613 \mathrm{MJ} / \mathrm{m}^{2}$ & $\alpha=816 \mathrm{~kW} / \mathrm{m}^{2}$ \\
& $\beta=89 \mathrm{MJ} / \mathrm{m}^{2}$ & $\beta=194 \mathrm{~kW} / \mathrm{m}^{2}$ \\
Whole apartment & Average $=665 \mathrm{MJ} / \mathrm{m}^{2}$ & Average $=928 \mathrm{~kW} / \mathrm{m}^{2}$ \\
& $\alpha=467 \mathrm{MJ} / \mathrm{m}^{2}$ & $\alpha=624 \mathrm{~kW} / \mathrm{m}^{2}$ \\
& $\beta=72 \mathrm{MJ} / \mathrm{m}^{2}$ & $\beta=148 \mathrm{~kW} / \mathrm{m}^{2}$ \\
& Average $=509 \mathrm{MJ} / \mathrm{m}^{2}$ & Average $=710 \mathrm{~kW} / \mathrm{m}^{2}$ \\
\hline
\end{tabular}


occupancies. However, the latter was determined across a limited floor area while the former was representative across the complete enclosure floor area.

Hietaniemi and Mikkola [35] simulated a series of residential fires, adopting statistical distributions for mass and the heat of combustion of furniture items located in hypothetical residential room layouts. Furniture items included sofas, armchairs, coffee tables, televisions, etc. Using the results of the simulations, Gumbel distributions were proposed which differed depending on the room of fire origin. The distribution parameters $(\alpha, \beta)$ for these distributions, as well as the average fire load density and equivalent HRRPUA, are given in Table 3.

\subsection{Other Types}

Early work by Klote and Milke [48] on the design of smoke management systems does not provide specific advice for HRRPUA. Subsequently Klote et al. [49] refer to BR 368 in the context of retail, office and library spaces, although they recommend that a value of $230 \mathrm{~kW} / \mathrm{m}^{2}$ be used for any space "where the major fuels would be transient fuels" and $650 \mathrm{~kW} / \mathrm{m}^{2}$ be considered for spaces with furniture or other combustible materials but with no further substantiation. Thus, spaces with furniture could potentially refer to both office and residential type occupancies. Klote et al. note that this approach is "rough" and that more detailed analysis can result in different design fires.

Fleischmann [50] provided 'general' recommended values for HRRPUA for use in fire safety design. To determine these values, Fleischmann considered average and maximum HRRPUA values recorded for polyurethane foam-fabric composites commonly found in upholstered furniture, from experiments undertaken by Denize [51]. For these fires, the average HRRPUA $\left(\overline{\dot{Q}^{\prime \prime}}\right)$ ranged from $165 \mathrm{~kW} / \mathrm{m}^{2}$ to $441 \mathrm{~kW} / \mathrm{m}^{2}$, with the maximum HRRPUA ranging from $262 \mathrm{~kW} / \mathrm{m}^{2}$ to $470 \mathrm{~kW} / \mathrm{m}^{2}$. Also discussed were much larger HRRPUA values determined for large-scale pool fires (maximum ranging from $498 \mathrm{~kW} / \mathrm{m}^{2}$ to $4505 \mathrm{~kW} / \mathrm{m}^{2}$ ) and stacked commodities $\left(245 \mathrm{~kW} / \mathrm{m}^{2}\right.$ to $\left.3118 \mathrm{~kW} / \mathrm{m}^{2}\right)$. The latter was determined from a summary by Babrauskas [52] provided in the second edition of the SFPE Handbook of Fire Protection Engineering, in turn taken from work by Alpert and Ward [53] and Delichatsios [54].

Alpert and Ward [53] summarised a series of stacked commodity experiments with the HRRPUA ranging from $35 \mathrm{Btu} / \mathrm{ft}^{2} / \mathrm{s}$ to $1500 \mathrm{Btu} / \mathrm{ft}^{2} / \mathrm{s}\left(400 \mathrm{~kW} / \mathrm{m}^{2}\right.$ to $17,000 \mathrm{~kW} / \mathrm{m}^{2}$ ), although it was not explicitly stated whether these represent average or maximum values. Similarly, Delichatsios [54] discussed 'small-scale' experiments of different palletised commodities, with each experiment covering a floor area of approximately $6.3 \mathrm{~m}^{2}$. The maximum HRR from these experiments ranged from $1.09 \times 10^{6} \mathrm{Btu} / \mathrm{min}$ to $7.06 \times 10^{6} \mathrm{Btu} / \mathrm{min}$, resulting in HRRPUA values ranging from $3000 \mathrm{~kW} / \mathrm{m}^{2}$ to $20,000 \mathrm{~kW} / \mathrm{m}^{2}$. The 'Valorisation Project: Natural Fire Safety Concept' [55] recommends a HRRPUA of $1250 \mathrm{~kW} / \mathrm{m}^{2}$ to $6000 \mathrm{~kW} /$ $\mathrm{m}^{2}$ for stacked commodities, depending on the stacked height and content.

A series of trial building cases were simulated by Fleischmann [50] to consider the sensitivity of varying HRRPUA in computational fluid dynamics software Fire Dynamics Simulator (FDS). Using the context of experimental values and 
FDS simulations, Fleischmann concluded with a recommended range of HRRPUA from $500 \mathrm{~kW} / \mathrm{m}^{2}$ to $1000 \mathrm{~kW} / \mathrm{m}^{2}$ for non-storage occupancies and $1000 \mathrm{~kW} / \mathrm{m}^{2}$ to $2500 \mathrm{~kW} / \mathrm{m}^{2}$ for storage occupancies. These recommended ranges were adopted in C/VM2 [11], specifying that "a range is provided... to accommodate different HRR and mesh sizes".

\section{Conclusions and Recommendations}

This review has highlighted how many of the design values in provided UK guidance for HRRPUA are ultimately derived from a small number of fire incidents and experiments described by Theobald $[12,13]$ in the 1970s. These fire incidents occurred in storage buildings, factories, workshops and a hospital research unit and were considered in combination with experimental data for wood cribs. The data was however subsequently adapted in various forms to consider shops and retail buildings, offices, hotel rooms and residential buildings. Variations in recommended values have occurred over time due to adjustments or differences in interpretation from various authors, including Law [27] and Morgan and Hansell [28, 29, 40]. Following this, proposed values were adopted in PD 7974-1:2003 [1], BS 7346-4:2003 [33], NFPA 92B [16] (and subsequent revisions [23, 44]), BR 368 [19] and CIBSE Guide E [5].

The review has attempted to highlight additional data available which relates specifically to the discussed occupancies and building types, although in certain instances they may still relate back to the work of Theobald. In the absence of further information, it is proposed that the ranges given in Table 4 may be adopted. These characterise the HRRPUA for either a specified average or maximum HRR for a representative fire footprint, and the selection of an applicable HRRPUA within these bounds will be dependent on the arrangement and quantity of anticipated fuel load. It is intended that these values will be incorporated into the revised edition of PD 7974-1. It is acknowledged that providing a range of values is less convenient than the single fixed values given currently in PD 7974-1:2003, in that fixed values can be more easily adopted and require limited consideration. Therefore, in adopting the revised values, designers will need to

\section{Table 4}

\section{Identified HRRPUA ranges available from literature}

\begin{tabular}{lll}
\hline Occupancy & HRRPUA $\left(\mathrm{kW} / \mathrm{m}^{2}\right)$ & \multicolumn{1}{c}{ References } \\
\hline Shops & $270-1200$ (maximum) & $\begin{array}{l}\text { Ghosh [32], Hinkley [20], Law [30] } \\
\text { and Morgan et al. [19] }\end{array}$ \\
Offices & $150-650$ (maximum) & $\begin{array}{l}\text { Ghosh [32] } \\
\text { Hotel rooms }\end{array}$ \\
Residential & 250 (average) & Hansell and Morgan [40] \\
Industrial & $320-570$ (maximum) & Fang and Breese [46] \\
Storage/stacked commodities & $90-620$ (average) & Theobald [12] \\
\hline
\end{tabular}


take greater care in considering the relevant source material in the context of the design problem and fire safety objectives.

The range of values given in Table 4 provides an opportunity for HRRPUA to be considered probabilistically, but distributions for such values would require further research intended to be undertaken by the authors of this paper. In addition, it would be beneficial for the recommended HRRPUA design values to be revisited in the context of modern building environments and their associated fuel loads.

\section{Compliance with Ethical Standards}

\section{Conflict of interest None.}

\section{Open Access}

This article is distributed under the terms of the Creative Commons Attribution 4.0 International License (http://creativecommons.org/licenses/by/4.0/), which permits unrestricted use, distribution, and reproduction in any medium, provided you give appropriate credit to the original author(s) and the source, provide a link to the Creative Commons license, and indicate if changes were made.

\section{References}

1. BSI (2003) Published Document, PD 7974-1:2003, Application of fire safety engineering principles to the design of buildings: Part 1 - initiation and development of fire within the enclosure of origin (sub-system 1). BSI Standards Publication

2. Drysdale D (2011) An introduction to fire dynamics, 3rd edn. Wiley, Chichester

3. Society of Fire Protection Engineers (2016) SFPE handbook of fire protection engineering, 5th edn. Springer, Berlin

4. CEN (2002) EN 1991-1-2: Eurocode 1: actions on structures - Part 1-2: general actions - actions on structures exposed to fire, European Committee for Standardization

5. CIBSE (2010) CIBSE Guide E, Fire safety engineering, 3rd edn., The Chartered Institution of Building Services Engineers

6. Staggs J (2005) Savitzky-Golay smoothing and numerical differentiation of cone calorimeter mass data. Fire Saf J 40(6):493-505

7. Evans D, Breden L (1977) NSBIR 77-1302, a numerical technique to correct heat release rate calorimetry data for apparatus time delay. National Bureau of Standards, Washington, DC

8. National Fire Protection Association (2009) NFPA 271, standard method of test for heat and visible smoke release rates for materials and products using an oxygen consumption calorimeter. NFPA, Quincy

9. Mowrer F, Williamson R (1990) Methods to characterize heat release rate data. Fire Saf J 16(5):367-387

10. Krasny J, Babrauskas V, Parker W (2001) Fire behaviours of upholstered furniture and mattresses. NoYes Publications, Norwich 
11. Ministry of Business, Innovation \& Employment (2014) C/VM2, verification method: framework for fire safety design, for New Zealand building code clauses C1-C6 protection from fire, 2014: New Zealand Government

12. Theobald C (1977) Growth and development of fire in industrial buildings. Fire Prev Sci Technol 17:4-16

13. Theobald C (1972) Fire research note no. 941, the effect of roof construction and contents on fires in single storey buildings. Fire Research Station, Borehamwood

14. Heselden A, Smith P, Theobald C (1966) Fire research note no. 646, fires in a large compartment containing structural steelwork, detailed measurements of fire behaviour. Fire Research Station, Borehamwood

15. Silcock A (1971) The survey of fires in buildings, fire survey group, first report October 1971. Fire Research Station, Borehamwood

16. National Fire Protection Association (1991) NFPA 92B, guide for smoke management system in malls, atria, and large areas, 1991 edn. NFPA, Quincy

17. Morgan HP (1979) Smoke control methods in enclosed shopping complexes of one or more storeys: a design summary. Building Research Establishment, Borehamwood

18. Hansell G, Morgan H (1994) BR 258, design approaches for smoke control in atrium buildings. Building Research Establishment, Borehamwood

19. Morgan HP, Ghosh BK, Garrad G, Pamlitschka R, Smedt JCD, Schoonbaert LR (1999) BR 368, design methodologies for smoke and heat exhaust ventilation. Building Research Establishment (BRE) Press, Bracknell

20. Hinkley PL (1971) Fire research note no. 875, some notes on the control of smoke in enclosed shopping centres. Fire Research Station, Borehamwood

21. Hinkley P (1975) Work by the fire research station on the control of smoke in covered shopping centres. Fire Research Station, Borehamwood

22. Law M (1995) The origins of the 5 MW design fire. Fire Saf Eng 2:343-346

23. National Fire Protection Association (2012) NFPA 92, standard for smoke control systems, 2012 edn. NFPA, Quincy

24. Draft for Development (1997) DD 240-1, fire safety engineering in buildings, part 1, guide to the application of fire safety engineering principles. BSI, London

25. Law M, Butcher G, Cox G, Hansell G, Mills F, Porter A, Thomas P, Trott C, Warren P (1995) Technical memoranda TM19:1995, relationships for smoke control calculations. The Chartered Institution of Building Services Engineers, London

26. Morgan HP, Gardner JP (1990) BR 186, design principles for smoke ventilation in enclosed shopping centres. Building Research Establishment (BRE) Press, Bracknell

27. Law M (1980) Air-supported structures: fire and smoke hazards. Arup J 15(3):11-13

28. Morgan H, Hansell G (1984) Fire sizes and sprinkler effectiveness in offices-implications for smoke control design. Fire Saf J 8:187-198

29. Morgan H, Hansell G (1987) Atrium buildings: calculating smoke flows in atria for smoke-control design. Fire Saf J 12(1):9-35

30. Law M (1986) Comments on "fire sizes and sprinkler effectiveness in offices-implications for smoke control design". Fire Saf J 10(1):67-68

31. Morgan H, Hansell G (1986) Reply to comments on "fire sizes on sprinkler effectiveness in offices - implications for smoke control design". Fire Saf J 10(1):69-70

32. Ghosh B (1997) Fires in real scenarios. In: International symposium on fire science and technology, Seoul, Korea, 1997

33. British Standard (2003) BS 7346-4:2003, components for smoke and heat control systems, functional recommendations and calculation methods for smoke and heat exhaust ventilation systems, employing steady-state design fires, code of practice. BSI Standards Publication, London 
34. Yuen WW, Chow WK (2005) A new method for selecting the design fire for safety provision. Fire Sci Technol 24(3):133-149

35. Hietaniemi J, Mikkola E (2010) VTT working papers 139, design fires for fire safety engineering. VTT Technical Research Centre of Finland

36. Madrzykowski D (1996) Office work station heat release rate study: full scale vs. bench scale. In: International interflam conference, Cambridge, England

37. Madrzykowski D, Walton W (2003) NIST special publication SP-1021, cook county adminstration building fire, 69 West Washington, Chicago, Illinois, October 17, 2003: heat release rate experiments and FDS simulations. National Institute of Standard and Technology, Gaithersburg

38. Kakegawa S, Yashiro S, Satoh Y, Kurioka H, Kasahara I, Ikehata Y, Saito N, Turuda $\mathrm{T}$ (2003) Design fires for means of egress in office buildings based on fuel-scale fire experiments. In: Fire safety science-proceedings of the seventh international symposium, Worcester, Massachusetts, 2003

39. Ohlemiller T, Mulholland G, Maranghides A, Filliben J, Gann R (2005) NIST NCSTAR 1-5C, fire tests of single office workstations. National Institute of Standards and Technology, Gaithersburg

40. Hansell G, Morgan H (1985) Fire sizes in hotel bedrooms-implications for smoke control design. Fire Saf J 8(3):177-186

41. Pettersson O, Magnusson O, Thor J (1976) Fire engineering design of steel structures, bulletin 52, publication 50. Swedish Institute of Steel Construction, Lund

42. Thomas P, Theobald C (1978) Growth and development of fire in industrial buildings, appendix: the burning rates and durations of fires. Fire Prev Sci Technol 17:15-16

43. Stern-Gottfried J, Rein G (2012) Travelling fires for structural design — part i: literature review. Fire Saf J 54:74-85

44. National Fire Protection Association (2018) NFPA 92, standard for smoke control systems, 2018 edn. NFPA, Quincy

45. Holborn P, Nolan P, Golt J (2004) An analysis of fire sizes, fire growth rates and times between events using data from fire investigations. Fire Saf J 39:481-524

46. Fang J, Breese J (1980) NBSIR 80-2120, fire development in residential basement rooms. Center for Fire Research, Washington, DC

47. Klote J, Milke J (2002) Principles of smoke management. American Society of Heating, Refrigerating and Air-conditioning Engineers, Atlanta

48. Klote JH, Milke JA (1992) Design of smoke management systems. American Society of Heating, Refrigerating and Air-conditioning Engineers, Atlanta

49. Klote J, Milke J, Turnbull P, Kashef A, Ferreira M (2012) Handbook of smoke control engineering. ASHRAE, Atlanta

50. Fleischmann C (2015) Defining the heat release rate per unit area for use in fire safety engineering analysis. In: Harada K, Matsuyama K, Himoto K, Nakamura Y, Wakatsusi K (eds) Fire Science and Technology 2015, Tsukuba, Japan

51. Denize HR (2000) Fire engineering research report 00/4, the combustion behaviour of upholstered furniture materials in New Zealand. University of Canterbury, Canterbury

52. Babrauskas V (1995) Burning rates. In: Dinenno P (ed) SFPE Handbook of Fire Protection Engineering. National Fire Protection Association, Quincy, pp 3-1-3-15

53. Alpert RL, Ward EJ (1984) Evaluation of unsprinklered fire hazards. Fire Saf J 7(2):127-143

54. Delichatsios M (1983) A scientific analysis of stored plastic fire tests. Fire Sci Technol 3(2):73-103 
55. Schleich J, Cajot L-G (2001) Valorisation project - natural fire safety concept. Profil Arbed, Luxembourg

Publisher's Note Springer Nature remains neutral with regard to jurisdictional claims in published maps and institutional affiliations. 